\title{
The Effect of Using Role Playing Strategy to the Students of Science Education
}

\author{
Fitria Eka Wulandari \\ Fakultas Keguruan dan Ilmu Pendidikan \\ Universitas Muhammadiyah Sidoarjo \\ Sidoarjo, Indonesia \\ fitriaekawulandari@umsida.ac.id
}

\begin{abstract}
This study aims to find out the influence of using role playing as the learning strategies for science education student in understanding scientific concept. This research is a quantitative descriptive research by using one group pretest and posttes research design. The data collection technique used in this research is saturated sampling The instrument used in this research is a written test upon student's cognitive learning outcomes. This test is used to expose student's ability to understand the concept of cell division material before and after the treatment performed. The analysis used in this research is descriptive quantitative by comparing before and after condition as the role playing is performed. The results of this research indicates that there is positive influence of role playing strategies. This is because the students are able to feel and actively experience as part of the learning process in mitosis and miosis stages. So, they become more familiar with the role they play and it makes them more anthusiastic to the material that they have to understand.
\end{abstract}

Keywordss-learning strategies; role playing; conceptual understanding

\section{INTRODUCTION}

Science learning is an effort within a process of understanding science principle and its entity. It covers studies on science products, creation process and scientific behavior cultivation as well as the application of scientific principles and facts to positively contribute toward the society. Study of cells, is a branch of science which focuses on the study of natural symptoms within the cell. This subject is an obligatory material for students majoring in Science Education. It starts with a comprehensive introduction to cell and continuing to deeper information about cell's structures and parts within.

Study of cell is considered as one of difficult subjects among Science Education students. During the learning process in the status quo, the students are only constructing their cognitive by reading scientific information without any direct experience or observation toward cell mechanism. This fact is then getting worse when they have to deal with printed book resources in foreign languages. Eventhough this material is one of main material in Science Education. It is also an obligatory material to pass as a determining requirement.

Knowing the background explained above, an interviewed is held to ten of eighteen students of Science Education. It then exposes that most of them have very low interest to the study of cell as they are complaining and grumbling on too many concepts and abstractions to memorize. This condition, perhaps, breaks class condusivity and brings the learning into the waste of time. This boredom will also eliminate their curiosity to the materials. A limited time to explore main resource books and learning instruments, along with low interest to the material itself, finally drop their learning output and result.

This ironic condition demands a way out and solution. A reconstruction of learning system is urgently needed to trigger student's interest toward the material. This interest will then contribute to a better learning process, student's motivation and perhaps their output and final result. According to Wilson, a study of cell in Biology is designed more than only text content observation and hearing concepts, but also contains ability to actively develop the students. An interesting learning process when it supply large opportunities for the students to massively construct their previous knowledge through the application of a student centred model. In a student centred model, students are guided to actively build their own scientific ideas to build their cognitive competence.

[6] mentioned that according to the recent research finding, a role play strategy can enhance student interest to a subject and materials. So then it can also positively influence students understanding upon the concepts. Moreover, before applying this learning strategy, students must also study about the characters and scenario which they apply. This study is projected to create a deeper understanding about each role they take. A Student's quality of understanding will influence others and finally 
realize a collective integration which then being presented to the viewers and audiences. [1] stated that A Historical Classes, where even the teachers are frustrated in response of minimum interest of students, can be direct into better condition using role playing strategy. In his observation, Fogg concluded that students are being more interested with the material. Based on this result of Fogg's observation, researcher is trying to apply the role playing strategy into the biological study of cell.

\section{METHOD}

This research is an experimental study which is held in April 2017. It took a place at The Science Education Major, Faculty of Education and Teaching, Muhammadiyah University of Sidoarjo. The study is subjecting eighteen students of the major, which contains three boys and fifteen girls. The students are in their sixth semester of the Undergraduate program. It is objecting specifically on the conceptual competence of the Biological study of cell. This study deploys descriptive and quantitative approach along with the pre-experimental design which contains "one group pre-test post-test".

The research is designed as below:

$$
\begin{array}{lll}
01 & \mathbf{X} & \mathbf{O 2}
\end{array}
$$

O1: The result of learning process before the treatment. X: A planned treatment during the learning process applying role playing strategy. O2: result of the learning process after the treatment. The evaluation upon understanding of the concept is done through Cognitive Test Sheet (Lembar Tes Hasil Belajar Kognitif) as instrument. A Quantitative and descriptive approaches are applied during the data analysis. It also utilizes the $\mathrm{G}$ factor ( $\mathrm{N}$-gain) to expose the enhancement and development at the final learning result by comparing 'before' and 'after' condition as the treatment (role playing model) is given during the learning process.

\section{FINDINGS AND DISCUSSION}

This research on the effect of of Using Role Playing Strategy to the Students of Education Science in Understanding concept of "the process of cell divison" Material exposes some beginning facts related to the students cognitive competences as detailed is some aspects; Knowledge (C1), Understanding (C2), Application (C3), Analysis (C4), Evaluation (C5) and Creation (C6). These aspects are explained in the graphic below:
Pre-test $\quad$ Post-test

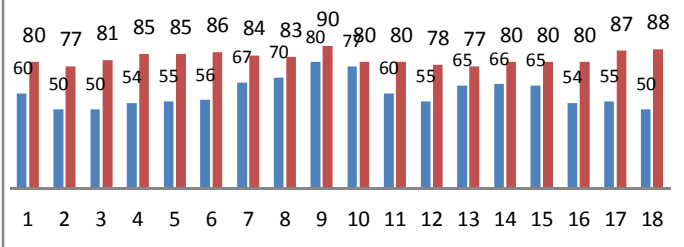

Fig. 1. Learning outcome of cell division

In graphic 1, the learning result of eighteen students in the pre-test is recorded. Sixteen students are reaching below standard of the minimum score (50-70). Meanwhile, two students have successfully passed beyond the standard (70 and 80). In average, students have reached classical score 60.5 of the cognitive competence (conceptual understanding). This record exposes a condition before the treatment which then explains that the students are averagely failed to go beyond the minimum targeted score (75).

Based on graphic 1, it is exposed that student's learning outcome, after the pots-test (after the treatment using role playing strategy is performed) is enhanced. The Eighteen students have reached the range of 77-90 score. This range has definitely passed the standard of minimum score (75) with 82.2 of classical average score. This finding leads to a conclusion that student's conceptual understanding is developed as the role playing strategy is applied during the learning process. Furthermore, the development surrounds both personal and classical.

The distinctive point specifically lies on the pretest and post-test score. As being recorded that before the treatment (performance of role playing strategy in learning process), students had only reached 60.5 of classical average score. Meanwhile, after the treatment and posttest, they have reached 82.2 of classical average score. In order to clarify the influence of role playing strategy, the g$\mathrm{N}$ is the utilized during the data analysis.

The learning result (conceptual understanding), both before and after the treatment are then being analyzed using g-N factor. It results 0.7 of g-N factor. It means when the ' $\mathrm{g}$ ' reached more than 0.7 , which also means a very significant positive influence toward the learning process. This fact also supports the previous conclusion that the learning outcome is developed using role playing strategy.

The positive influence of role playing toward the learning process is determined by active interaction 
between the students during the learning process. Their collaboration in order to present a good show for the viewers and audiences has successfully motivated them to fulfil the learning target. During the collaboration, students are sharing their knowledge each other. [2] role playing is a learning model which is categorized in the social learning model. Role playing deploys so many social aspects during student's interaction in the learning process. A cooperative behaviour is believed to stimulate both social and intellectual development.

Along with interactions among individuals inside the class, [3] also stated that the role playing strategy is also a dynamic play in which aimed to a specific target, rules as well as enjoyment. During the application of role playing strategy, students are set in a specific condition outside the class, while actually they are still under regular supervision inside the class. This condition is also happening during the study of cell, in chapter 'The process of Cell divisions'. The students are given a one month time to discuss -within their each group- about certain scenario of how do the cell perform a division. The result upon students development is also supporting [1] research report which stated that role playing is positively enhance students participation during the learning process. In role playing strategy, the learning process must go through several steps; [4] Course Objectives Selection: in this step, course objectives and outcome target are set up. [5]Selection of Role, Context and Scenario: in this step, students are working together with the lecturer to decide certain role and context to apply then continuing to the construction of the scenario. [6]Introductory Drilling: as the construction of scenario is finished, some of the students are being choosen or voluntarily propose himself to take the role based on the set scenario. After that, each student will start to drill themselves under the lecturer supervisions and guidance.

The drilling is continuously held several days before the real performance. During this time, they are having many chances to learn deeper about the characters which they are taking to play. [1] The Learning day/Performance day: in the learning day, all well trained students will perform their roles in front of the class. Another student will watch the performances and then discuss the contents with their group mates. The discussion points are compiled in a student worksheet (LKM). [2]Discussion, Evaluation and Conclusion: as the performances are done, each student can discuss, comment and evaluate the performances they watched under the guidance of the lecturer. Each of group are then demanded to communicate their final conclusion. At this point, lecturer will also present some comments and feedbacks. [3] Scoring: the scoring is awarded based on the role playing quality which is done by the students. Deeper understanding about the character according to the set scenario is also determining factor to the score awarding.

The role playing strategy has successfully taught the students to express empathy and utilization of multiple points of view. This is quite understandable since the role playing is so much exploiting emotional aspects. For the cognitive domain, this exploitation is positive for motivating students to share their knowledge each other in order to create a good integration during the performance. By performing certain role, students are being set to feel others feeling and position. With this role playing strategy, they will not easily judge someone or problems until utilizing multiple points of view. And finally, all students are projected to easily understand the whole material which is being communicated through a role playing. The audiences and viewers also actively participate through their observation, comments and critics. These positive influences are determined by the quality of the role playing along with its following analysis, student's perception and the reality.

Believed that role playing can provide chances for students to play certain role of individual who is familiar to them. By this experience, students will directly feel the sensation of being their favourite character. This experience will trigger them to be more sensitive upon surrounding problems in their lives. Their interpersonal skill and communications are also being developed well [7].

\section{CONCLUSION}

The use of role playing in the learning process is excellent, especially in enhancing conceptual understanding. It also contains some unique aspects in which students are allowed to freely interact among them in order to create a scenario. Feeling of empathy during this interaction triggers them to share their knowledge each other in order to present a good performance. Massive participation from all class members creates conductivity and levels up their learning motivations. In determining thema of lecturers must guide students actively so that the scenarios generated in accordance with the learning outcomes.

\section{ACKNOWLEDGMENT}

We acknowledged Universitas Muhammadiyah Sidoarjo. 


\section{REFERENCES}

[1] P. Fogg, "A history professor engages students by giving them a role in the action," Chronicle of Higher Education. 2001.

[2] M. Joyce, B. R., \& Weil, "Role Playing; Studying Social Behavior and Values," in Models of Teaching. Allyn and Bacon., 2000.

[3] Hadfield, Classroom Dynamic. Oxford: University Press, 1986.

[4] A. H. Wilson, "Equilibrium : A Teaching/Learning Activity," J. Chem. Educ., vol. 75, no. 9, pp. 11761177, 1998.

[5] B. P. Huddle, "Conceptual Questions on
LeChatelier's Principle. Education," J. Chem., vol. 75, no. 9, p. 1175, 1998.

[6] P. B. Poorman, "Biography and roleplaying:fostering empathy in abnormal psychology," Teaching of Psychology. 2002.

[7] L. JOYNER, Beres; YOUNG, "Teaching medical students using role play: twelve tips for successful role plays," Med. Teach., vol. 28, no. 3, pp. 225229, 2006. 